\title{
The relationship between personality, customer participation, customer value and customer satisfaction in tourism service
}

\author{
Cedric Hsi-Jui Wu ${ }^{1}$ and Ali Mursid ${ }^{2 *}$
}

Received: 01/02/2019 Accepted: 17/06/2019

\begin{abstract}
1 Department of Business Administration, National Dong Hwa University, No. 1, Section 2, Da-Hsueh Road, Shou-Feng, Hualien, Taiwan, Republic of China

2 Ph.D. Candidate in Department of Business Administration, National Dong Hwa University, No. 1, Section 2 , Da-Hsueh Road, Shou-Feng, Hualien, Taiwan, Republic of China and Senior Lecturer in Department of Management, Bank BPD Jateng School of Economics and Business, Pemuda Street 4A, Semarang, Central Java, Indonesia. Email ali.mursyid14@gmail.com
\end{abstract}

* Corresponding author

Coordinating editor: Giacomo del Chiappa

\begin{abstract}
This study discusses the effects of the Big Five personality traits, namely extraversion, openness, agreeableness, consciousness, and neuroticism, on customer participation in tourism service. Moreover, it verifies the relationship between customer participation, functional value, emotional value and customer satisfaction. The data analysis employs confirmatory factor analysis (CFA) and structural equation modeling with a total sample of 496 tour participants. The results show the personality traits of extraversion, openness, and agreeableness significantly affect customer participation, while consciousness and neuroticism insignificantly affect customer participation. Customer participation directly affects customer satisfaction. In addition, customer participation has positive effects on functional value and emotional value, and, subsequently, functional value and emotional value affect customer satisfaction.
\end{abstract}

Keywords: personality, customer participation, customer value and customer satisfaction

Citation: Wu, C., A. Mursid (2019) The relationship between personality, customer participation, customer value and customer satisfaction in tourism service. European Journal of Tourism Research 23, pp. 156-171

\section{Introduction}

Traveling has become a primary need for every family in Indonesia. People join tour activities not only to take a break from their daily routines and relieve stress but also to spend quality time with their family. The Indonesia Minister of Tourism reported that the total number of domestic tourists from January to November 2016 reached more than 288 million (Kompas, 2016). The above annual phenomena has

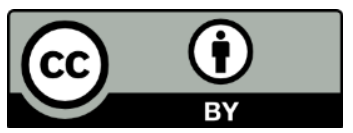

156
This work is licensed under the Creative Commons Attribution 4.0 International (CC BY 4.0). To view a copy of this license, visit https://creativecommons.org/licenses/by/4.0/ 
encouraged this study to further explore tourist behavior and outcomes, particularly for family vacationers.

The theory of service-dominant logic developed by Vargo and Lusch (2004) suggests that customers are not only passive receivers, but also active participants in determining value. The interaction between the service provider and customer offers a form of collaboration in the process of value creation building upon the position of customers as partners (Vargo and Lusch, 2008). Yi and Gong (2013) proposed a multi-dimensional approach to measuring customer value co-creation by distinguishing between customer participation (in role behaviour) and voluntary customer activities (extra-role behaviour). Following the recommendation from Prebensen and Xie (2017) to adopt a more comprehensive measurement of value co-creation, this study focuses on customer participation in tourism services by adapting the measurement scale from Yi and Gong (2013).

Scholars have elucidated the antecedents of customer participation in value co-creation in the context of hospitality and tourism from the customers' perspective. Grisseman and Stokburger-Sauer (2012) explored company support for customers to identify the level of customer co-creation value. Moreover, Im and Qu (2017) investigated perceived physical environment and perceived support for customers to identify customer value cocreation. Other studies have examined the antecedents of customer participation based on psychological factors such as mood regulatory process (Taheri et al., 2017) and emotions (Malone et al., 2018). Though the determining factors of customer participation in value cocreation have been elucidated by many researchers, previous studies have never included customer personality traits. Therefore, this study intends to fill the research gap by exploring the relationship between the Big Five personality traits and customer participation in tour agency services.

The subsequent contributions elucidate the relationship between customer participation and customer satisfaction. Some authors have found that customer participation directly impacts customer satisfaction in tourism settings (Grissemann and Stokburger-Sauer, 2012; Lu et al., 2015). Conversely, Wu (2011) failed to demonstrate the direct effect of customer participation on customer satisfaction in tourist destinations. Therefore, this study attempted to revisit this relation by exploring the functional value and emotional value emerging in the relationship between customer participation and customer satisfaction.

More precisely this study aims to shed light on customer participation in tourism services based on the Big Five personality traits, which include extraversion, openness, agreeableness, consciousness, and neuroticism. Furthermore, we examine the direct effect of customer participation on customer satisfaction. Finally, this framework verifies the relationship of customer participation with functional value and emotional value and in turn the effects of functional value and emotional value on customer satisfaction.

\section{Literature Review and Hypotheses Development}

The big five personality traits and customer participation in value co-creation

Scholars have explored the influence of personality traits on employee behaviour e.g. the relationship between personality traits and organizational citizenship behaviour (Helle, Deshong, Lengel, Meyer, Butler, and MullinsSweatt, 2018; Bourdage, Goupal, Neilson, Lukacik, and Lee, 2018) or personality traits and job performance (Judge and Zapata, 2015). Moreover, another study examined personality traits impact on customer attitude in self-production (Huynh and Olsen, 2015). The above researches inspire this study to verify how personality traits affect customer participation in value co-creation of tourists in Indonesia.

Personality refers to distinctive individual thought, behaviour, and emotions to adapt to certain situations in life (Jani, 2011). Moreover, Ying and Norman (2017) showed that the Big Five personality traits have been recognized and commonly used in the psychology and tourism literature. Moreover, in the tourism business, it is necessary to consider how service employees with different personalities 
perform network tasks. This study adopted the Big Five personality traits proposed by Barrick and Mount (1991), including extraversion, openness, agreeableness, consciousness, and neuroticism, which have been widely accepted in previous studies.

Extraversion is defined as the personality trait of being outgoing, extroverted, emphatic, conversational, and energetic (Barrick and Mount, 1991). Another study described this character as the degree to which an individual is confident, dominant, dynamic, talkative and passionate (Zhao and Seibert, 2006). A person who has an extraverted character prefers being around many people to being alone (LePine and Dyne, 2001). Extraversion is associated with the extent to which a person is active, emphatic and sociable (Fayombo, 2010).

Openness refers to the characteristics of a person who has curiosity about improving their knowledge, enjoying new challenges and expressing innovative ideas (Zhao and Seibert, 2006). A person who possesses a high level of openness tends to be innovative, imaginative, inquisitive and unconventional (George and Zhou, 2001, McCrae and Costa, 1985, McCrae and John, 1992, Costa and McCrae, 1992, Fayombo, 2010). Such a person thinks philosophically and loves art (McCrae and John, 1992). On the contrary, a person who has a low degree of openness has a tendency to be conservative and uncritical and lack interest and comfort (McCrae and Costa, 1987).

Agreeableness is the orientation to having positive and cooperative relationships (Digman, 1990, Zhao and Seibert, 2006). Kuo et al. (2015) pointed out that agreeable individuals can be described are credulous, harmonious, generous and kind. Agreeable people tend to conform to social consensus and have high quality relationships; they also tend to be accommodating, believing, sympathetic, moderate, kind, tolerant, and cooperative (Barrick and Mount, 1991, Costa and McCrae, 1992). Conversely, a person who has a low level of agreeableness is likely to be egoistic, distrustful, and antagonistic (Feist, 1998).

Conscientious people tend to be systematized, diligent, persistent, and motivated in pursuing 158 an objective achievement (Zhao and Seibert, 2006). This kind of person is detail-oriented, well organized, inclined to respect regulation, consistent and responsible (Fayombo, 2010). A person who has a high level of conscientiousness displays dependability, selfdiscipline, and achievement motivation (Mount and Barrick, 1995); this kind of person prefers to arrange a good systematic, plan rather than taking impulsive actions (Barrick et al., 2001a).

Neuroticism is defined as a negative emotional trait representing emotional uncertainty (Myers et al., 2010). A neurotic person demonstrates unstable emotional change and negative effects such as nervousness, self-doubt, and resentment (Judge et al., 2002). Moreover, a person who has a high level of neuroticism has negative manners, is uneasy and poorly socialized (LePine and Dyne, 2001). This kind of person is often unbalanced, miserable, and worried (Yoo and Gretzel, 2011). Contradictory to neuroticism, a person with emotional stability is peaceful, tolerant, secure, and familiar (Feist, 1998, McCrae and Costa, 1987).

Value co-creation refers to a collaboration between a company and customers to communicate intensively in providing quality products or services in the process of consumption (Prahalad and Ramaswamy, 2004). The concept of value co-creation can guide firms to understand customer needs and wants (Lusch and Vargo, 2006). Payne et al. (2008) suggested that the process of value cocreation includes procedures, tasks, mechanisms, activities, and interactions. Customer participation refers to the level of customer involvement in effort, preference, and knowledge as well as other contributions to provide and deliver a service (Chan et al., 2010).

Previous studies investigating the Big Five personality traits and pro-environmental behavior stimulated this study to propose some hypotheses related to the Big Five personality traits and customer participation. Fraj and Martinez (2006) reported that personality positively and significantly influences ecological behavior. Moreover, Hirsh (2010) found that high rating of agreeableness and openness enhance environmental concern. Conversely, a 
greater level of neuroticism and consciousness reduce environmental concern. Another study conducted by Kvasova (2015) showed that agreeableness,

conscientiousness, extraversion, and neuroticism positively affect pro-environmental behaviour, while openness insignificantly affects ecological action. Milfont and Sibley (2012) presented that agreeableness, consciousness, and openness to experience have a close relationship to environmental engagement.

In a tourism setting, a previous study showed that tourists' personality traits affect tour motivation and interest in different ways (Scott and Mowen, 2007). Lin et al. (2014) described how personality leads to fluctuations of emotions among visitors on their vacation. Furthermore, personality affects the degree of anxiety and unhappiness and moderately impacts disgust throughout tourists' vacations, while, openness has a direct effect on traveller attitudes regarding tourism phenomena (Ong and Musa, 2012). Malone, McKechnie, and Tynan (2018) described in qualitative study related to how emotions contribute to the process of customer value co-creation in the context of tourism. Another study showed that various customer personality characteristics positively and negatively affect customer engagement behaviour (Chen et al., 2017). Moreover, Taheri, Coelho, Sousa, and Evanschitzky (2017) reported that mood monitoring and mood repair directly affect the customer participation of hotel customers; therefore, this study proposes the following hypotheses.

H1: Extraversion positively affects customer participation.

H2: Openness positively affects customer participation.

H3: Agreeableness positively affects customer participation.

H4: Consciousness positively affects customer participation.

H5: Neuroticism negatively affects customer participation.

\section{Customer Participation and Customer}

\section{Satisfaction}

The term of customer satisfaction denotes the evaluation of an outcome that confirms expected rewards or the comparison between cost and expected benefit (Churchill and Surprenant, 1982). Researchers have yet to clearly show direct interaction between customer participation and customer satisfaction. Wu (2011) could not prove that customer participation predicts customer satisfaction directly and positively in the context of tourism. Conversely, Grissemann and Stokburger-Sauer (2012) pointed out that the degree of value co-creation impacts customer satisfaction with a tourism service company. Similarly, Lu et al. (2015) reported customer involvement affects customer satisfaction with a tourist destination. A more recent study informed the calculation model of customer value co-creation behaviour include customer participation and customer voluntary behaviour impact on customer satisfaction (Clauss, Kesting, and Naskrent, 2018). Therefore, this study purposes the following hypothesis.

H6: Customer participation positively and significantly impacts customer satisfaction.

\section{Customer Participation, Functional Value and Emotional Value}

Zeithaml (1988) defined customers' perceived value as customers' overall evaluation of a product in relation to what is obtained and what is given. Some factors determine customer perception, including both monetary and nonmonetary factors, customer tastes, and customer characteristics (Bolton and Drew, 1991). The concept of customer value has been described in various terms and through different methods, and has thus become challenging to revisit (Gallarza et al., 2011). A current study conducted by Liu (2017) explained that value in a tourism setting consists of conservation, education, recreation and research. Moreover, Gudem et al. (2013) stated that customer value changes dynamically depending upon the attributes of a product, corporate image, market issues, and customer experience.

This study attempts to include functional value and emotional value to verify the relationship between customer participation and customer satisfaction. Functional value refers to the function, useful as well as the physical performance of the product perceived by a consumer (Sheth et al., 1991). In tourism, 
functional value often indicates the amount of attraction that can be seen, speed of service performance, comfort of seat facilities, price and security (Williams and Soutar, 2005). Moreover, emotional value indicates the customer's feeling toward a product based on the aspect of social psychology (Sheth et al., 1991). Emotional value has been considered as an important factor in evaluation of customer satisfaction (Otto and Ritchie, 1996).

Oh (1999) recommended combining customer value to mediate service quality and customer satisfaction. Furthermore, firms use dynamic value perceptions, comprised of values, desired value, and value judgment, to describe the emergence of customer wants, value, and satisfaction (Flint et al., 1997). The traveller's emotion partially mediates between the relationship of physical environments and customer satisfaction (Moon et al., 2016). Zainuddin and Russel-Bennett (2013) found that co-production, as a construct customer participation, does not affect functional value in health care service. On the contrary the current study conducted by Hau et al. (2017) reported the significant effect of customer participation on customers' perceived value. Moreover, Prebensen and Xie (2017) demonstrated that both physical and psychological co-creation in tourism settings significantly impact perceived value. Therefore, this study offers the following hypotheses.

H7: Customer participation positively and significantly impacts functional value.

H8: Customer participation positively and significantly impacts emotional value.

Functional Value, Emotional Value and Customer Satisfaction

Lee et al. (2012) pointed out that social value signficantly impacts disclose information, behavioral, and attitudinal loyalty, while economic value only affects behavioral loyalty in a restaurant context. Moreover, exploring customer response on a travel website, Wu et al. (2014) reported that utilitarian value significantly affects attitude and purchasing intention. Yang and Peterson (2004) testified that a customer's perceived value affects customer satisfaction. Similarly, Wang et al. (2004) showed that customer value comprises emotional value, functional value, social value and perceived sacrifice, all of which significantly impact customer satisfaction.

Another study conducted by Flint et al. (2011) stated that customer value perception is dynamic and constantly changing. Thus, this type of perception must be anticipated. This study found that customer value affects customer satisfaction and loyalty. In tourism setting, Castellanos-Verdugo et al. (2017) reported that shopping value affects souvenir shopping satisfaction. Focusing on functional value and emotional value, Zainuddin and Russel-Bennett (2013) found that functional value and emotional value significantly affect customer satisfaction in the social marketing of health care service. Likewise, Williams and Soutar (2009) reported that in adventure tourism, functional value and emotional value significantly affect customer satisfaction. A current study conducted by Choi, Lawry, and Kim (2019) identified that economic value, emotional value, and relational value impact customer satisfaction. Therefore, we purpose the following hypotheses.

\section{H9: Functional value positively and significantly} affects customer satisfaction.

H10: Emotional value positively and significantly affects customer satisfaction.

\section{Study Framework}

This study verifies the Big Five personality traits (extraversion, openness, agreeableness, consciousness and neuroticism) as the determinant factors of customer participation in tour service. Moreover, this framework investigates the direct influence of customer participation and customer satisfaction. Finally, it examines the impact of customer participation on functional value and emotional value and then investigates the effects of these two values on customer satisfaction. Figure 1 depicts the research framework.

\section{Methodology}

Sample and Data Collection

This study collected data to test a model associated with customer participation in a tour agency service in Semarang City, Indonesia. The questionnaires were distributed to eight tour agencies that offer tours taking several 


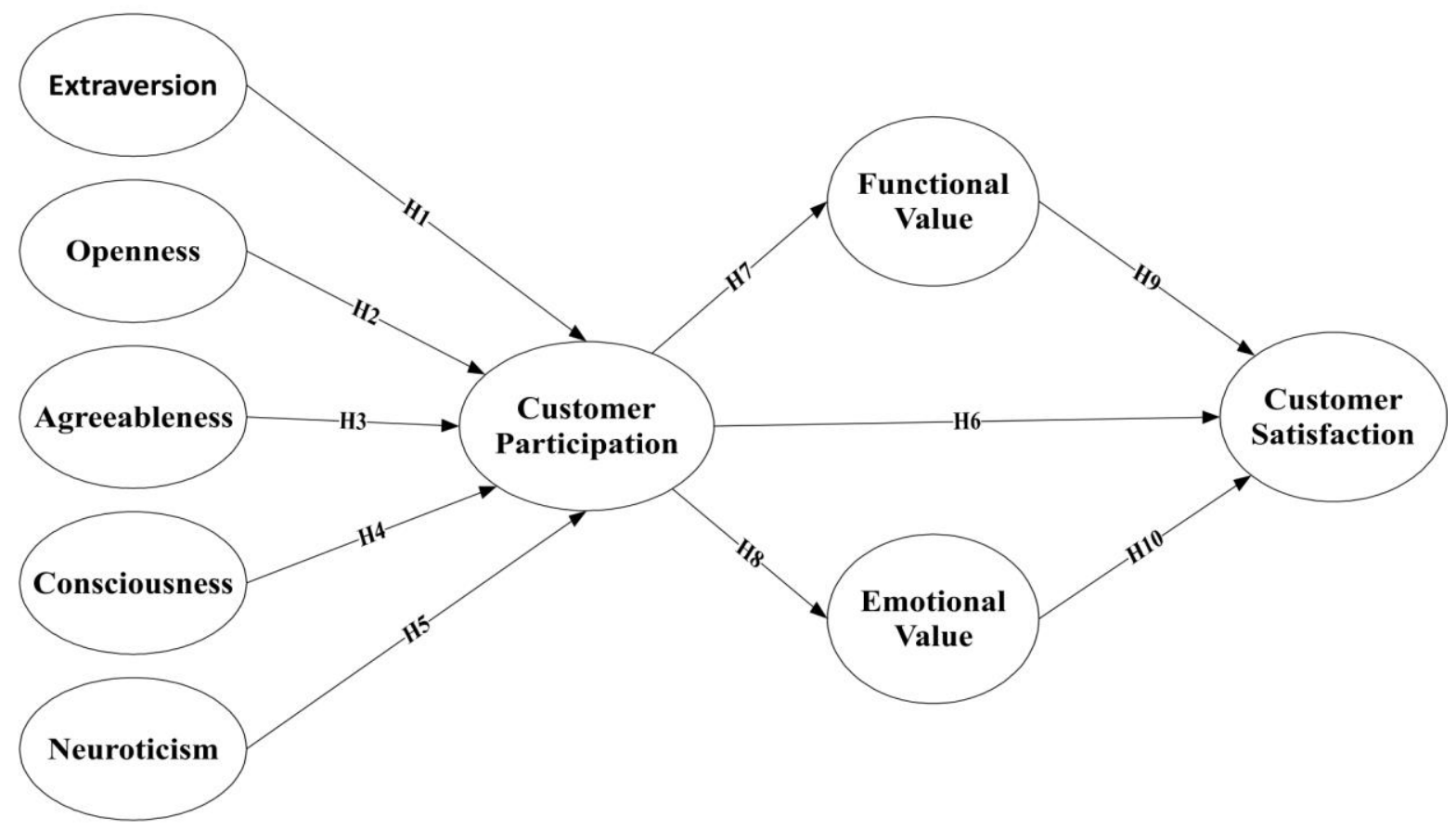

Figure 1. Theoretical framework

days to interesting tourist destinations in Indonesia such as Bali, Bandung, Malang, and Lombok during the summer vacation of 2016 . In regard to participants' gender, we found a higher number of females than males; thus, our data collection used quota sampling $(60 \%$ female and $40 \%$ male). Sixteen undergraduate students assisted the respondents in filling out the questionnaires and one junior lecturer supervised and coordinated the distribution of all of the questionnaires. Eight tour agencies helped the process of data collection with 800 questionnaires. Each tour agency was given 100 questionnaires to distribute to the tour participants and the respondents completed the questionnaires after finishing the tour. Approximately 537 questionnaires returned with a response rate of $67 \%$. This study analysed the data from 496 completed questionnaires to verify the framework.

\section{Measurement}

This study used measurement scales developed by previous research and then we modified the items scale to match with responses of tour participants and translated them into the Indonesian language. The dimensions of the Big Five personality traits were modified from those used by Yoo and Gretzel (2011) to include extraversion, openness, agreeableness, consciousness, and neuroticism. Furthermore, the customer participation measurement was considered more complete and the dimensions were kept brief, following Yi and Gong (2013). This scale treated customer participation as a secondorder measurement consisting of four submeasurements, namely information seeking, information sharing, responsible behaviour, and personal interaction. Customer value includes both functional value and emotional value; thus, the measurement used here followed the approach of Sweeney, while the last variable of customer satisfaction was borrowed from Gremler and Gwinner (2000). The questionnaires were answered based on a 7 point scale from $1=$ very strongly disagree to 7 $=$ very strongly agree. This study also presented socio-demographics of respondents' profiles such as age, gender, marital status, income and level of education.

\section{Results}

The analysis of the measurement scale of this study reported that all dimensions possessed Cronbach's alphas of greater than 0.7 as 
recommended (Nunnaly, 1978). The dimensions of the Big Five customer personality traits resulted the Cronbach's alphas of each trait exceeding 0.7 for Extraversion (0.707), Openness (0.778), Agreeableness (0.846), Consciousness (0.765), and Neuroticism (0.782). The items scale of customer participation as a secondorder measurement consisting of four submeasurements (information seeking, information sharing, responsible behavior, and personal interaction) resulted in Cronbach's alphas of $0.724,0.767,0.770$, and 0.837 , respectively. Customer value includes functional value with a Cronbach's alpha of 0.751 and emotional value with a Cronbach's alpha of 0.754 . The last variable of customer satisfaction achieved a Cronbach's alpha of 0.783 .

\section{Descriptive Statistics}

The profile of respondents' socio-demographics showed that the proportion of females is higher than that of males and data collection almost reached the total number of target respondents (60\% female and $40 \%$ male). Female participants in this study achieved $58.9 \%$ and male respondents reached $41.1 \%$. Moreover, the average age was dominated by 31 to 40 year olds $(61.3 \%)$, followed by those between 41 and 50 years old (33.3\%). The majority of the respondents received a monthly income of more than IDR 5000.000 and less than IDR
15.000 .000 (94.4\%), were married (87.9\%) and pursued undergraduate education (86.1\%). A detailed description of this profile is depicted in Table 1.

\section{Confirmatory Factor Analysis}

The analysis used the confirmatory factor in structural equation modeling with two-step analysis including measurement and structural equational modeling (Anderson and Gerbing, 1988). Bagozzi and Yi (1988) recommended the meaningful criteria, i.e. the entire factor loading should not be too low $(<0.5)$ or too high ( $>0.95$ ). Moreover, the values of average variance extracted (AVE) in every construct were above the threshold of 0.5 and composite reliabilities $(\mathrm{CR})$ were all greater than 0.7 . All items fulfilled the criteria with AVE reaching between 0.502 and 0.725 and $C R$ ranging from 0.720 to 0.879 . The analysis tested reliability and validity of the measurement analysis are shown in Table 2.

Finally, to demonstrate the consistency of the measurement item, we show that every construct reached a squared root of $A V E$ higher than the correlation estimate (Table 3), thus confirming discriminant validity.

The result of the measurement scale showed a good model fit as recommended by Anderson and Gerbing (1988), with chi-square $=824.559$, a degree of freedom $(D F)=412$, and CMIN/DF

Table 1. Socio-demographics description of research participants

\begin{tabular}{|c|c|c|c|}
\hline \multicolumn{2}{|c|}{ Variable of socio-demographics } & $\begin{array}{l}\text { Total respondents } \\
(\mathrm{n})\end{array}$ & $\begin{array}{l}\text { Percentage of } \\
\text { respondents }\end{array}$ \\
\hline \multirow[t]{2}{*}{ Gender } & Male & 204 & 41.1 \\
\hline & Female & 292 & 58.9 \\
\hline \multirow[t]{4}{*}{ Aqe } & $20-30$ vears old & 19 & 3.8 \\
\hline & $31-40$ vears old & 304 & 61.3 \\
\hline & $41-50$ vears old & 165 & 33.3 \\
\hline & $51-60$ vears old & 8 & 1.6 \\
\hline \multirow[t]{2}{*}{ Marital status } & Sinqle & 60 & 12.1 \\
\hline & Marriage & 436 & 87.9 \\
\hline \multirow[t]{3}{*}{ Education } & Senior Hiah School & 19 & 3.8 \\
\hline & Underaraduate & 427 & 86.1 \\
\hline & Master & 50 & 10.1 \\
\hline \multirow[t]{3}{*}{ Monthlv income } & $<$ IDR 5.000 .000 & 23 & 4.6 \\
\hline & $\begin{array}{l}\text { IDR } 5000.000-\text { IDR }< \\
15.000 .000\end{array}$ & 468 & 94.4 \\
\hline & >IDR15.000.000 & 5 & 1.0 \\
\hline
\end{tabular}


Wu, C., A. Mursid (2019) / European Journal of Tourism Research 23, pp. 156-171

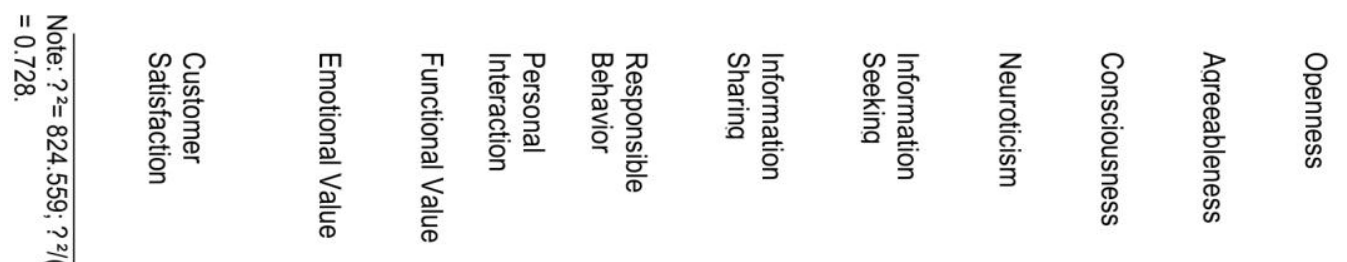

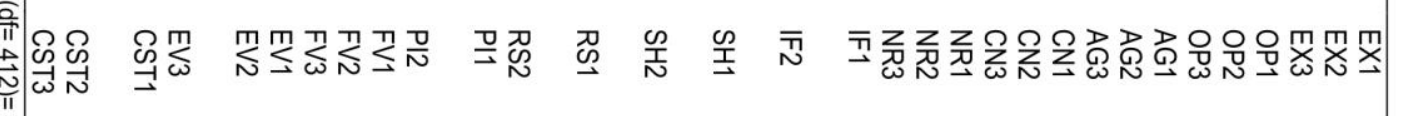
II

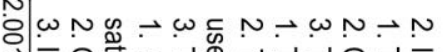

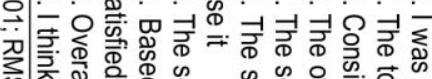

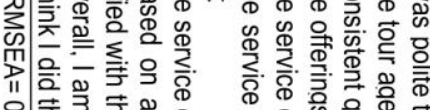

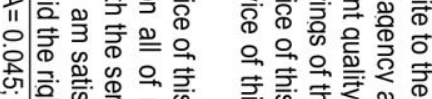

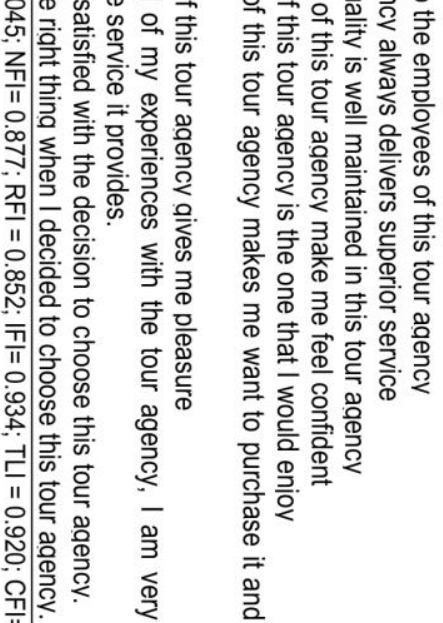

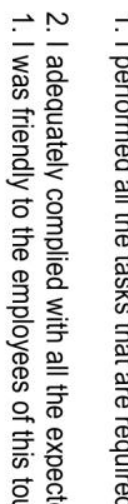

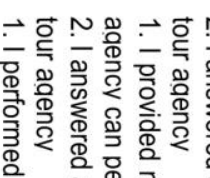

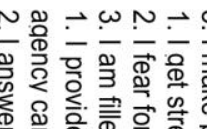

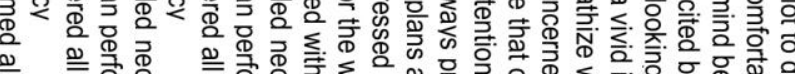

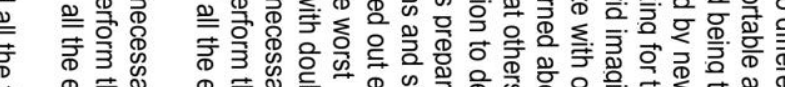

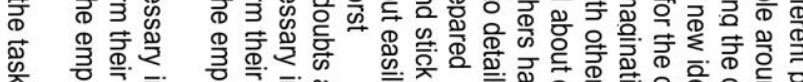

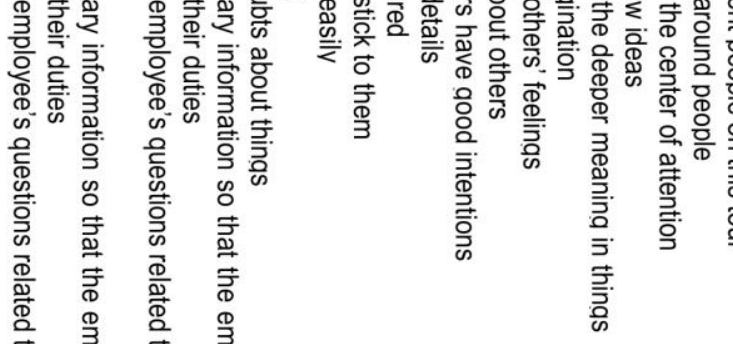

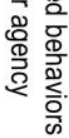

察

응ㅇㅇㅇㅇㅇㅇㅇㅇㅇㅇㅣ

డి

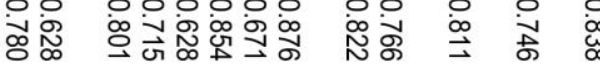

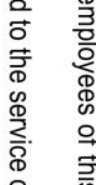

空

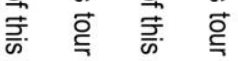

ग्र

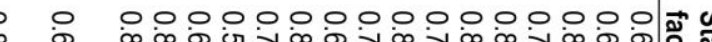

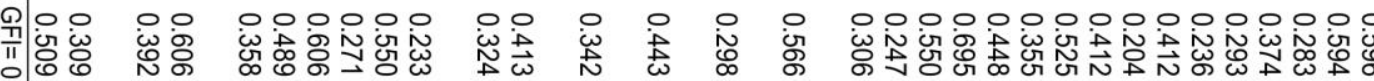

。․

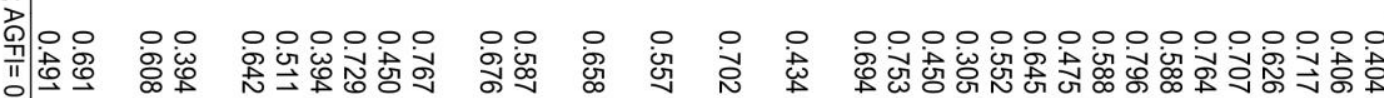

$\stackrel{\infty}{\mathrm{G}}$

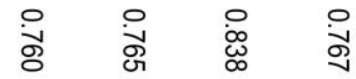

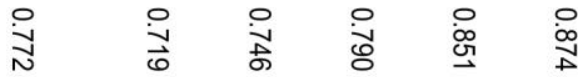

$\stackrel{\circ}{\rightarrow} \quad$ 이

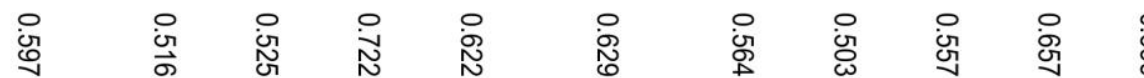

융 응

咅

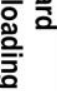

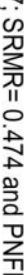

$\stackrel{\circ}{\stackrel{\omega}{\omega}}$

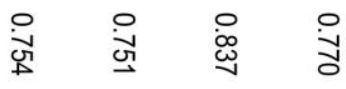

옥

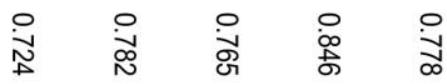

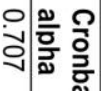


The relationship between personality, customer participation, customer value and customer satisfaction in tourism service.

$=2.001$. Moreover, the goodness of fit $(\mathrm{GFI})=$ 0.906 , IFI $=0.934$, Tucker Lewis index $(T L I)=$ 0.920 , comparative fit index $(\mathrm{CFI})=0.934$, root mean square error of approximately (RMSEA) $=0.045$ and standard RMR (SRMR) $=0.047$. Bagozzi and Yi (1988) recommended that IFI and GFI of above 0.9 are acceptable. Moreover, approximate model fit of less than 0.05 for RMSEA and SRMR $<0.08$ are considered indicative of close fit, thus, the analysis can be continued to the structural model (Hu and Bentler, 1998).

The results of reliability and validity on the structural model show good model fit. The entire factor loading was greater than 0.5 and less than 0.95, AVE was higher than 0.5 and CR surpassed 0.7 . The value of AVE reached between 0.503 and 0.722 ; moreover the value of CR ranged from 0.719 to 0.874 (Bagozzi and $\mathrm{Yi}, 1988)$. The analysis of the structural model also indicated model fit fulfillment with chi square $=894.292$, DF $=428$, and $\mathrm{CMIN} / \mathrm{DF}=$ 2.089. Furthermore, $\mathrm{GFI}=0.901, \mathrm{IFI}=0.926$, $\mathrm{TLI}=0.913$, and $\mathrm{CFI}=0.925$. The value of $\mathrm{IFI}$, TLI, CFI and GFI were greater than 0.9, indicating the model fit (Bagozzi and Yi, 1988). Moreover, RMSEA $=0.047$, thus fulfilling the recommended model fit of less than 0.05 and $\mathrm{SRMR}=0.055$ with a meaningful value $<0.08$ (Hu and Bentler, 1998).

The hypotheses testing showed that three factors of customer personality, namely extraversion, openness and agreeableness, positively and significantly affect customer participation (Hypothesis 1,2 and 3), while the two factors of consciousness and neuroticism insignificantly affect customer participation
(Hypothesis 4 and 5). Furthermore, customer participation directly affects customer satisfaction (Hypothesis 6). The relationship between customer participation and customer satisfaction also becomes effective through customer value. The result indicates that customer participation has direct effects on functional and emotional value (Hypothesis 7 and 8) and in turn, functional value and emotional value affect customer satisfaction (Hypothesis 9 and Hypothesis 10). The detailed results are shown in Table 4.

\section{Conclusion}

This study verifies the Big Five personality traits, including extraversion, openness, agreeableness, consciousness, neuroticism, predict customer participation in a tour agency service. Moreover, it examines the direct effect of customer participation on customer satisfaction. Lastly, this framework examines the functional value and emotional value evolving in the relationship between customer participation and customer satisfaction.

The result reported that three personality traits, namely extraversion, openness, and agreeableness, significantly affect customer participation, while consciousness and neuroticism insignificantly influence customer participation. The findings also confirm that customer participation has a direct effect on customer satisfaction. Examining the functional value and emotional value emerging in the relationship between customer participation and customer satisfaction in this framework is fruitful. It shows that customer participation significantly affects both functional value and emotional value, and in turn, functional value

Table 3. Discriminant validity

\begin{tabular}{|c|c|c|c|c|c|c|c|c|c|}
\hline Dimension & EX & OP & $\mathbf{A G}$ & $\mathrm{CN}$ & NR & CPT & FV & EV & CST \\
\hline EX & 0.715 & & & & & & & & \\
\hline OP & 0.081 & 0.841 & & & & & & & \\
\hline$A G$ & -0.034 & 0.586 & 0.811 & & & & & & \\
\hline $\mathrm{CN}$ & 0.032 & 0.517 & 0.749 & 0.747 & & & & & \\
\hline NR & -0.310 & -0.229 & -0.293 & -0.365 & 0.708 & & & & \\
\hline CPT & 0.224 & 0.499 & 0.485 & 0.443 & -0.271 & 0.798 & & & \\
\hline FV & 0.175 & 0.217 & 0.216 & 0.189 & -0.055 & 0.438 & 0.721 & & \\
\hline EV & 0.252 & 0.311 & 0.215 & 0.174 & -0.129 & 0.477 & 0.593 & 0.718 & \\
\hline CST & 0.217 & 0.260 & 0.152 & 0.150 & -0.140 & 0.510 & 0.446 & 0.534 & 0.775 \\
\hline
\end{tabular}

Note: main diagonals display the square root of AVE value and the off-diagonals indicate the correlation estimates between two variables. 
Table 4. Result of hypothesis testing

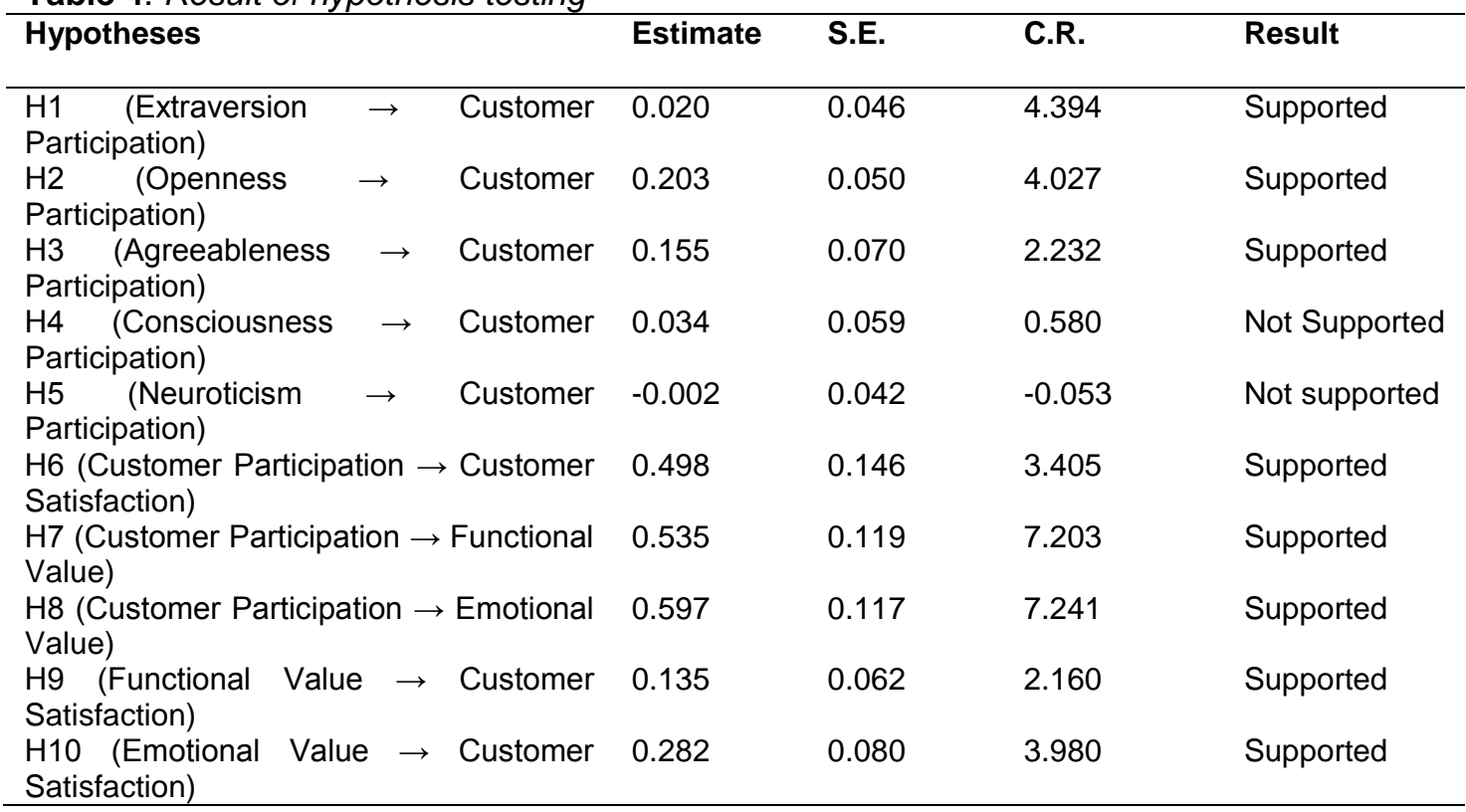

and emotional value significantly impact customer satisfaction.

This finding contributes to the body of knowledge of customer participation in value co-creation stimulated by Vargo and Lusch (2004) and Prahalad and Ramaswamy (2004), especially in articulating three positive factors among the Big Five personality traits, namely extraversion, agreeableness and openness, as the determinant factors of customer participation. This study clarifies the relationship between customer participation and customer satisfaction in two ways. First, customer participation has a direct effect on customer satisfaction and secondly, customer participation impacts functional value and emotional value and subsequently, functional value and emotional value influence customer satisfaction.

\section{Discussion}

The results of this study confirms that three personality traits, namely extraversion, agreeableness, and openness, affect customer participation. These results are consistent with previous studies showing that agreeableness and extraversion positively impact proenvironmental behaviour (Kvasova, 2015). The findings also support prior research revealing that a high rating of agreeableness and openness enhance environmental concern (Hirsh, 2010); agreeableness and openness to experience are closely related to environmental engagement (Milfont and Sibley, 2012). In the tourist context, the personality trait of openness is supported in the study by Ong and Musa (2012) who stated that openness has a direct effect on traveller attitudes regarding tourism phenomena and Taheri et al (2017), who reported that mood monitoring and mood repair impact customer participation. This finding strengthens the notion that extraversion, agreeableness, and openness directly affect behaviour in the form of customer participation, especially in tourism service.

Two of the customer personality traits, namely consciousness and neuroticism, did not affect customer participation as expected. A potential explanation, referring to Barrick et al. (2001), is that three aspects of personality including extraversion, agreeableness and openness are effective in determining performance for a particular job with several criteria. For instance, to accomplish a job, many communication characteristics such as being friendly, expressive, emphatic, creative, imaginative, active, and motivated are included in extraversion and openness. Agreeableness is 
also essential to engaging in serving, collaborating and fostering others. Based on the above reasons, this study focused on tour services whose services involve high levels of interaction so that three of the factors are more dominant, while consciousness and neuroticism do not appear.

Regarding the relationship between customer participation and customer satisfaction, the results agree with the majority of previous works that have reported the direct interaction between customer participation and customer satisfaction (Grissemann and StokburgerSauer, 2012, Lu et al., 2015, Clauss et al. 2018). The result shows that customer participation has a strong direct effect on customer satisfaction, even in tourism. However, this finding does not agree with the study by Wu (2011), which could not verify the influence of customer participation and customer satisfaction in the tourism setting. The result strengthens the finding that customer participation directly affects customer satisfaction.

Adding the construct of customer value in the relationship between customer participation and customer satisfaction is also revealing since this framework found a clearer interaction. The analysis of this relationship showed that customer participation affects functional value and emotional value. The result supports the recent investigation from Hau et al. (2017) who reported the significant effect between customer participation and customer value. The result of this study shows the importance of perceived value as the consequences of customer participation is consistent with the findings of Prebensen and Xie (2017) in the tourism context.

The effects of functional value and emotional value on customer satisfaction are also consistent with previous studies showing that customer perceived value affects customer satisfaction (Yang and Peterson, 2004, Flint et al., 2011). Moreover, Wang et al. (2004) showed that all aspects of customer value, including emotional value, functional value, social value and perceived sacrifice, significantly impact customer satisfaction. This finding also supports the recent study conducted by Choi, et al. (2019) that reported economic value, emotional value, and relational value affect customer satisfaction. Focusing on functional value and emotional value, the result is consistent with Zainuddin and RusselBennett (2013), who explained that functional value and emotional value significantly affect customer satisfaction, and Williams and Soutar (2009) showed that functional value and emotional value significantly affect customer satisfaction in adventure tourism.

Based on the results, the direct effect of customer participation on customer satisfaction is lower than the effect of customer participation on customer satisfaction through customer value. The finding shows that the total effect of customer participation on customer satisfaction is 0.498 , while the effect of customer participation on functional value is 0.535, the effect of functional value on customer satisfaction is 0.135 (the total effect is 0.660 ), the effect of customer participation on emotional value is 0.597 , and, in turn, the effect of emotional value on customer satisfaction is 0.282 (the total effect is 0.879). Although customer participation directly affects customer participation in tourism services, the relationship between customer participation and customer satisfaction through functional value and emotional value is more effective.

\section{Practical Implications}

Based on these findings related to the big five personality traits and customer participation, service firms like tour agencies should emphasize several factors to stimulate customer participation in value co-creation. Considering customer personality traits such as extraversion, openness, and agreeableness is crucial in encouraging customers to participate in value co-creation. The service employees of tour agency services can identify the participants who tend to have certain personality traits, notably extraversion, openness, and agreeableness, to collaborate in value co-creation in order to provide excellent service during tour activities. In this case, the role of the tour leader in building harmonious communication and displaying exciting performance during the tour is of the utmost importance. The management of tour agencies can train employees deliver superior service 
and serve customers with different kinds of personality traits.

The direct effect of customer participation on customer satisfaction or through functional and emotional value give two alternatives for tour agency services to build customer satisfaction. First, the service employees of tour agencies can motivate tour participants to participate in the service process, and second, tour agencies can offer functional value or emotional value to enhance their satisfaction. It is important for managers of tour agencies to build media to promote communication between customers and service employee. Such media can improve customer participation and satisfy the customer by creating both functional value, such as quality of the service, and emotional value, like enjoyment and pleasure.

\section{Limitations and Suggestions for Future Research}

This study has attempted to examine the Big Five personality traits as antecedents of customer participation and the effects of customer participation on customer satisfaction through customer value. However, we have encountered some limiting factors. The framework focuses on customer participation in tour agencies so that the findings cannot be generalized. We recommend that future research explore different samples from other tourism industries such as hotels, airlines, restaurants, etc., to examine how the Big Five traits affect customer participation. Moreover, another measurement of personality traits can be explored to predict customer participation. Extending customer participation in value cocreation in the context of green tourism with green value co-creation and in religious tourism settings such as spiritual tourist co-creation value and so on would be exciting topics for future study.

A recommendation for future research is to identify consequences beyond customer satisfaction such as those related to customer loyalty. This would elicit an even more comprehensive explanation. In such cases, scholars could explore customer participation to predict customer loyalty by extending perceived value beyond functional and emotional value. Finally, investigating the relationship quality between customer satisfaction, customer trust, and customer commitment emerging in the relationship between customer participation and customer loyalty would also be useful in future studies.

\section{References}

Anderson, J.C., and Gerbing, D. W. (1988). Structural equation modelling in practice: a review and recommended two-step approach. Psychological Bulletin, 103 (3), 411-423.

Bagozzi, R. P., and Yi, Y. (1988). On the evaluation of structural equation models. Journal of the Academy of Marketing Science, 16 (1), 74-94.

Barrick, M. R., and Mount, M. K. (1991). The big flve personality dimensions and job performance: a meta-analysis. Personnel Psychology 44 (1), 1-26.

Barrick, M. R, Mount, M. K, and Judge, T. A. (2001). Personality and performance at the beginning of the new millennium: what do we know and where do we go next? International Journal of Selection and Assessment, 9 (1-2), 9-30.

Bolton, R. N., and Drew, J. H. (1991). A multistage model of customers' assessments of service quality and value. Journal of Consumer Research, 17 (4), 375-384.

Bourdage, J. S., Goupal, A., Neilson, T., Lukacik, E. R., \& Lee, N. (2018). Personality, equity sensitivity, and discretionary workplace behavior. Personality and Individual Differences, 120, 144-150.

Bove, L. L., Pervan, S. J., Beatty, S. E. and Shiu, E. (2009). Service worker role in encouraging customer organizational citizenship behaviors. Journal of Business Research 62 (7), 698-705.

Castellanos-Verdugo, M., M. Oviedo-Garcia, M. Vega-Vázquez (2017). Souvenir shopping satisfaction: antecedents and consequences. European Journal of Tourism Research 17, 191-205

Chan, K. W., Yim, C. K. B., and Lam, S. S. K. (2010). Is customer participation in value creation a double-edged sword? evidence from professional financial services across cultures. Journal of Marketing, 74 (3), 4864. 
Chan, S. H. J., Wan, Y. K. P., and Wong, I. K. A. (2015). Exploring the differences among Chinese casino gamblers' characteristics, motivations, and behaviors. Journal of Vacation Marketing, 21, 23-36.

Chen, S.C., Raab, C., and Tanford, S. (2015). Antecedents of mandatory customer participation in service encounters: an empirical study. International Journal of Hospitality Management, 46, 65-75.

Chen, X., Yu, H., Gentry, J. W., and Yu, F. (2017). Complaint or recommendation? the impact of customers' state and trait goal orientations on customer engagement behaviors. Journal of Consumer Behavior, 16 (2), 187-194.

Choi, L., Lawry, C. A., \& Kim, M. (2019). Contextualizing customer organizational citizenship behaviors: The changing nature of value cocreation and customer satisfaction across service settings. Psychology \& Marketing, 1-18. https://doi.org/10.1002/mar.21190.

Churchill, J., and Suprenant, C. (1982). An investigation into the determinants of customer satisfaction. Journal of Marketing Research, 19, 491-504.

Clauss, T., Kesting, T., \& Naskrent, J. (2018). A rolling stone gathers no moss: the effect of customers' perceived business model innovativeness on customer value co-creation behavior and customer satisfaction in the service sector. $R \& D$ Management, 1-24. RADMA and John Wiley \& Sons Ltd.

Costa, P. T., and Miccrae, R. R. (1992). The five factor model of personality and its relevance to personality disorders. Journal of Personality Disorders, 6 (4), 343-359.

Digman, J. M. (1990). Personality structure: emergence of the five-factor model. Annual Review of Psychology, 41 (1), 417-440.

Fayombo, G. (2010). The relationship between personality traits and psychological resilience among the caribbean adolescents. International Journal of Psychological Studies, I2 (2), 105-116.

Feist, G. J. (1998). A meta-analysis of personality in scientific and artistic creativity. Personality and Social Psychology Review, 2 (4), 290-309.
Flint, D. J., Blocker, C. P., and Boutin-JR, P. J. (2011). Customer value anticipation, customer satisfaction and loyalty: an empirical examination. Industrial Marketing Management, 40 (2), 219-230.

Flint, D. J., Woodruff, R. B., and Gardial, S. F. (1997). Customer value change in industrial marketing relationships a call for new strategies and research. Industrial Marketing Management, 26 (2), 163-175.

Fraj, E., and Martinez, E. (2006). Influence of personality on ecological consumer behavior. Journal of Consumer Behavior, 5 (3), 167-187.

Gallarza, M. G., Gil-Saura, I., and Holbrook, M. B. (2011). The value of value: further excursions on the meaning and role of customer value. Journal of Consumer Behavior, 10 (4), 179-191.

George, J. M., and Zhou, J. (2001). When openness to experience and conscientiousness are related to creative behavior: an interactional approach. Journal of Applied Psychology, 86 (3), 513-524.

Gilbert A. Churchill, J., and Suprenant, C. (1982). An investigation into the determinants of customer satisfaction. Journal of Marketing Research, 19, 491-504.

Gremler, D. D., and Gwinner, K. P. (2000). Customer-employee rapport in service relationships. Journal of Service Research, 3 (1), 82-104.

Grissemann, U. S., and Stokburger-Sauer, N. E. (2012). Customer co-creation of travel services: the role of company support and customer satisfaction with the co-creation performance. Tourism Management 33 (6), 1483-1492.

Groth, M. (2005). Customers as good soldiers: examining citizenship behaviors in internet service deliveries. Journal of Management, 31(1), 7-27.

Gudem, M., Steinert, M., Welo, T., and Leifer, L. (2013). Redefining customer value in lean product development design projects. Journal of Engineering Design and Technology, 11 (1), 71-89.

Hau, L. N., Anh, P. N. T., \& Thuy, P. N. (2017). The effects of interaction behaviors of service frontliners on customer participation in the value co-creation: a study of health care service. Service Business, 11(2), 253-277. 
Helle, A. C., DeShong, H. L., Lengel, G. J., Meyer, N. A., Butler, J., \& Mullins-Sweatt, S. N. (2018). Utilizing Five Factor Model facets to conceptualize counterproductive, unethical, and organizational citizenship workplace behaviors. Personality and Individual Differences, 135, 113-120.

Hirsh, J. B. (2010). Personality and environmental concern. Journal of Environmental Psychology, 30 (2), 245-248.

Hsiao, C., Lee, Y. H., and Chen, W. J. (2015). The effect of servant leadership on customer value co-creation: a cross-level analysis of key mediating roles. Tourism Management, 49, 45-57.

Hu, L.-T., and Bentler, P. M. (1998). Fit indices in covariance structure modeling: sensitivity to underparameterized model misspecification. Psychological Methods 3 (4), 424-453.

Huynh, M. T. X., \& Olsen, S. O. (2015). Personality, Personal Values, and Consumer Participation in Self-Production: The Case of Home Meal Preparation. Psychology \& Marketing, 32(7), 709724.

Jani, D. (2011). The Influence of personality on tourist information behavior. e-Review of Tourism Research (eRTR), 9 (3), 88-95.

Judge, T. A., \& Zapata, C. P. (2015). The person-situation debate revisited: Effect of situation strength and trait activation on the validity of the Big Five personality traits in predicting job performance. Academy of Management Journal, 58(4), 1149-1179.

Judge, T. A., Bono, J. E., Ilies, R., and Gerhardt, M. W. (2002). Personality and leadership: a qualitative and quantitative review. Journal of Applied Psychology, 87 (4), 765-780.

Kompas (2016). Berwisata sudah menjadi kebutuhan penting. Available in https://www.presreader.com.

Kuo, N. T., Cheng, Y. S., Chiu, W. H., and Cho, S. (2016). Personalities of travel agents with strong sales records in taiwan. Asia Pacific Journal of Tourism Research, 21 (9), 1-19.

Kvasova, O. (2015). The big five personality traits as antecedents of eco-friendly tourist behavior. Personality and Individual Differences, 83, 111-116.
Lee, A., Lambert, C. U., and Law, R. (2012). Customer preferences for social value over economic value in restaurants. Asia Pacific Journal of Tourism Research, 17 (5), 473-488.

Lepine, J. A., and Dyne, L. V. (2001). Voice and cooperative behavior as contrasting forms of contextual performance: evidence of differential relationships with big five personality characteristics and cognitive ability. Journal of Applied Psychology, 86 (2), 326-336.

Lin, Y., Kersteter, D., Nawijn, J., and Mitas, O. (2014). Changes in emotions and their interactions with personality in a vacation context. Tourism Management, 40, 416424.

Liu, S.-T. (2017). A partial least squares structural equation modeling approach for examining multidimensional values of taipei zoo. Asia Pacific Journal of Tourism Research, 22 (8), 863-873.

Lu, L., Chi, C. G., and Liu, Y. (2015). Authenticity, involvement, and image: evaluating tourist experiences at historic districts. Tourism Management 50, 85-96.

Lusch, R. F., and Vargo, S. L. (2006). Servicedominant logic: reactions, reflections and refinements. Marketing Theory, 6 (3), 281288.

Malone, S., McKechnie, S., \& Tynan, C. (2018). Tourists' emotions as a resource for customer value creation, cocreation, and destruction: A customer-grounded understandding. Journal of Travel Research, 57(7), 843-855.

McCrae, R. R., and Costa, Jr. (1997). Personality trait structure as a human universal. American Psychologist, 52 (5), 509-516.

McCrae, R. R., and Costa, P. T. (1985). Updating norman's "adequate taxonomy": intelligence and personality dimension in natural language and in questionnaires, Journal of Personality and Social Psychology, 49 (3), 710-721.

McCrae, R. R., and Costa, P. T. (1987). Validation of the five-factor model of personality across instruments and observers. Journal of Personality and Social Psychology, 52 (1), 81-90.

McCrae, R. R., and John, O. P. (1992). An Introduction to the five-factor model and 
The relationship between personality, customer participation, customer value and customer satisfaction in tourism service.

its applications. Journal of personality 60 (2), 175-215.

Milfont, T. L., and Sibley, C. G. (2012). The big five personality traits and environmental engagement: associations at the individual and societal level. Journal of Environmental Psychology, 32 (2), 187-195.

Moon, H., Yoon, H. J., and Han, H. (2016). Role of airport physical environments in the satisfaction generation process: mediating the impact of traveller emotion. Asia Pacific Journal of Tourism Research, 21 (2), 193-211.

Mount, M., and Barrick, M. (1995). The big five personality dimensions: implications for research and practice in human resources management. Research in personnel and human resources management, 13 (3), 153-200.

Myers, S., Sen, S., and Alexandrov, A. (2010). The moderating effect of personality traits on attitudes toward advertisements: a contingency framework. Management \& Marketing, 5 (3), 3-20.

Navarrro, S., Llinares, C., and Garzon, D. (2015). Exploring the relationship between co-creation and satisfaction using QCA. Journal of Business Research, 69 (4), 1336-1339.

Nunnaly, J. C. (1978). Psychometric Theory, New York, NY, Mc-Graw-Hill.

Oh, H. (1999). Service quality, customer satisfaction, and customer value: a holistic perspective. International Journal of Hospitility Management 18 (1), 67-82.

Ong, T. F., and Musa, G. (2012). Examining the influences of experience, personality and attitude on scuba divers' underwater behavior: a structural equation model. Tourism Management, 33 (6), 1521-1534.

Otto, J. E., and Ritchie, J. R. B. (1996). The service experience in tourism. Tourism Management, 17 (3), 165-174.

Payne, A. F., Storbacka, K., and Frow, P. (2008). Managing the co-creation of value. Journal of the Academic Marketing Science, 36 (1), 83-96.

Prahalad, C. K., and Ramaswamy, V. (2004). Co-creating unique value with customers. Strategy \& Leadership, 32 (3), 4-9.

Prebensen, N. K., and Xie, J. (2017). Efficacy of co-creation and mastering on perceived value and satisfaction in tourists' consumption. Tourism Management 60, 166-176.

Revilla-Camacho, M. Á., Vega-Vazquez, M., and Cossio-Silva, F. J. (2015). Customer participation and citizenship behavior effects on turnover intention. Journal of Business Research 68 (7), 1607-1611.

Scott, K., and Mowen, J. C. (2007). Travelers and their traits: a hierarchical model approach. Journal of Consumer Behavior, $6(2-3), 146-157$.

Sheth, J. N., Newman, B. I., and Gross, B. L. (1991). Why we buy what we buy: a theory of consumption values. Journal of Business Research, 22 (2), 159-170.

Sweeney, J. C., and Soutar, G. N. (2001). Consumer perceived value: the development of a multiple item scale. Journal of Retailing, 77 (2), 203-220.

Taheri, B., Coelho, F. J., Sousa, C. M., \& Evanschitzky, H. (2017). Mood regulation, customer participation, and customer value creation in hospitality services. International Journal of Contemporary Hospitality Management, 29(12), 3063-3081.

Varasteh, H., Marzuki, A., and Rasoolimanesh, S. M. (2015). Factors affecting international students's travel behavior. Journal of Vacation Marketing, 21, 31-149.

Vargo, S. L., and Lusch, R. F. (2004). Evolving to a new dominant logic for marketing. Journal of Marketing, 68 (1), 1-17.

Wang, Y., Lo, H. P., Chi, R., and Yang, Y. (2004). An integrated framework for customer value and customer-relationship-management performance: a customer-based perspective from china. Managing Service Quality, 14 (2/3), 169-182.

Wells, R. A., Gallarza, M. G., Andreu, L., and Calero, R. (2015). Application of service dominant logic to the medical device industry. International Review on Public Nonprofit Marketing, 12 (2), 207-235.

Williams, P., and Soutar, G. (2005). Close to the "edge": critical issues for adventure tourism operators. Asia Pacific Journal of Tourism Research, 10 (3), 247-262.

Williams, P., and Soutar, G. N. (2009). Value, satisfaction, and behavioral intentions in an adventure tourism context. Annals of Tourism Research, 36 (3), 413-438. 
Wu, C. H.-J., Li, H.-J., and Chiu, C.-W. (2014). Understanding consumer responses to travel websites from online shopping value and flow experience perspectives. Tourism Economics, 20 (5), 1087-1103.

Wu, C. H-J. (2011). A re-examination of the antecedents and impact of customer participation in service. The Service Industries Journal, 31 (6), 863-876.

Yang, Z., and Peterson, R. T. (2004). Customer perceived value, satisfaction, and loyalty: the role of switching costs. Psychology \& Marketing 21 (10), 799-822.

Yi, Y. and Gong, T. (2013). Customer value cocreation behavior: scale development and validation. Journal of Business Research, 66 (9), 1279-1284.

Ying, T. and Norman, W. C. (2017). Personality effects on the social network structure of boundary-spanning personnel in the tourism industry. Journal of Hospitality \& Tourism Research, 41 (5), 515-538.
Yoo, K.-H., and Gretzel, U. (2011). Influence of personality on travel-related consumergenerated media creation. Computers in Human Behavior, 27 (2), 609-621.

Zainuddin, N., and Russel-Bennet, R. (2013). The value of health and wellbeing: an empirical model of value creation in social marketing. European Journal of Marketing, 47 (9), 1504-1524.

Zeithaml, V. A. (1988). Consumer perceptions of price, quality, and value: a means-end model and synthesis of evidence. Journal of Marketing 52, 2-22.

Zhao, H., and Seibert, S. E. (2006). The big five personality dimensions and entrepreneurial status: a meta-analytical review. Journal of Applied Psychology, 91 (2), 259-271. 